\title{
THE UNITY OF TRUE PEOPLE IN THE ACCOUNTING OF THE CHURCH TRITUGAS
}

\author{
Kiet Tumiwa, Jolly Turangan, Lusye C. Kumaat, Johana Ratag \\ Department of Accounting, Polytechnic of Manado Country \\ DOI: $10.31364 / \mathrm{SCIRJ} / \mathrm{v} 7.110 .2019 . P 1019712$ \\ http://dx.doi.org/10.31364/SCIRJ/v7.i10.2019.P1019712
}

\begin{abstract}
Church-tritugas accounting is a form of service in the unity of the hearts of the righteous, which is inseparable, including: Koinonia (fellowship), Marturia (preaching / witnessing), and diakonia (doing / serving). The purpose of this research, to find meaning, church tritugas accounting is done by all Christians. The research method used, namely qualitative methods, to understand the phenomena about what is experienced by research subjects, about actions and motivations holistically and by describing in the form of words and language, in a special natural context, and by utilizing various methods naturally in revealing an object under study. The results showed that the meaning of church tritugas accounting is that the financial information generated is based on the unity of the hearts of the righteous, there is no modification (corruption) even though life is in need. Hopefully this research can motivate church finance managers to continue to use church tritugas accounting as a guide in managing church finances.
\end{abstract}

Keywords: Unity of Heart, Church Assignment Accounting.

\section{INTRODUCTION}

Church organizations have great hopes for unity, in fostering human resources in managing finances on the principle of church tritugas. Their activities are not only focused on seeking donations, but also winning souls, such as: human resource development, visit of the sick, visit of people in prison, placement of refugees and many others. The source of funds from this church organization, comes from donations from members of the congregation, which are collected from various church activities. Therefore, church organizations are required to have a true unity of heart on the principle of church tritugas in making financial reports to congregants, for donations received, as well as their contribution to the congregation, and other communities who need it.

PSAK No. 45 of 2012 concerning financial reporting of non-profit entities, states that non-profit organizations are required to prepare financial reports, and report to users of financial statements. The Christian non-profit organization in this research is the church. The church is a type of non-profit organization, which can be seen as a grazing business unit, by using management responsibilities in managing human, financial and other resources to achieve perfect financial statement information.

The financial statements of church organizations provide true information to meet the interests of donors, members of the organization, creditors, and other parties who provide resources for the church organization, and demonstrate management's responsibility for the use of resources entrusted to them. Thus, it is understood that the church organization requires management accountability for adequate financial arrangements in the form of financial reporting in the unity of the church tritugas. .

Church tritugas is a non-profit entity in the service of the righteous, which is inseparable, including: koinonia, marturia and diakonia. In the church tritugas dimension, accounting is clearly described, Nothing in all creation is hidden from God's sight. Everything is uncovered and laid bare before the eyes of him to whom we must give account (Hebrews 4:13). Church tritugas accounting is an instrument of responsibility for the work of serving the earth's ruler, namely God, and is used as a solution to resolve conflicts (Gallhofer, 2011). The accountability of the work of the church organization's services to donors made in the form of accounting information, is a reflection that the religious organization has experienced success or failure. Stanbury (2003) states that accounting is a form of accountability for the success, or failure of the implementation of an organization's mission, in achieving its stated goals and objectives, through periodic means of accounting. Based on the above background, the researcher is interested in finding out the meaning of the accounting of church tritugas in the G church in Manado.

\section{RESEARCH METHODS}

The research method used, namely qualitative methods, to understand the phenomena about what is experienced by research subjects, about actions and motivations holistically and by describing in the form of words and language, in a special natural context, and by utilizing various methods naturally in revealing an object under study. Researchers depart from the subject (human) and his consciousness and strive to return to pure awareness. Basic researchers choose qualitative research methods.

First, in the process of data retrieval, researchers sought to enter the point of view of the practitioners of the church tritugas accounting practices, so that they could clearly understand their activities, which had been developed by each individual over time. Furthermore, the researcher tries to also understand the mindset of the practitioners of the church tritugas accounting practices, to shape their personal experiences of events in their lives as they are, in carrying out the activities of church tritugas. 
That is, the field situation under study is a phenomenon that is truly what it is, taking into account the context in which the phenomenon occurs. The situation in this research field is natural, as it is without manipulation and without being regulated by experimentation (Nasution, 1992).

Second, human instruments. The researcher merges directly together with practitioners of accounting practices in church organizations, and is oriented towards finding, exploring, expanding and describing data holistically, in the form of written or oral words and observed informant behavior, and supported by literature studies or literature studies based on deepening literature study, so that reality can be understood properly. Moleong (2008) said that researchers themselves are the main data collection tools, so that researchers can easily adjust to reality in the field, which cannot be done other than humans, and are able to understand reality on the ground by participating in research sites. The data generated from this process is in the form of qualitative data, so that the analysis and interpretation of the data is inductive by prioritizing the feelings, norms, beliefs, habits, mental and cultural attitudes adopted by informants as practitioners of the church tritugas accounting practices.

Third, practitioners of the church tritugas accounting practices are the object or informant of this study. In an effort to disclose an object under research, qualitative research can be used to uncover various uniqueness found in individuals, groups, communities or organizations in daily life as a whole, in detail, in depth, and can be justified scientifically (Basrowi, 2002). Therefore, this research is more oriented to the process of uncovering the uniqueness behind the meaning of a phenomenon (social reality) accounting for church tritugas, which is not expressed before the congregation holistically, and does not reduce the phenomenon into variables. Then the relationship is sought partially, but researchers carry this phenomenon as part of a whole and real. In this research, researchers sought to understand values and meanings based on information provided by informants. By using the subjectivity approach, and trying to interpret the situation as it is, and photographing deeper reality about accounting practices in church organizations, from the point of view of the informant in his life as a research subject.

Fourth, the findings of the researcher are negotiated again with the informants as practitioners of the church tritugas accounting practices, meaning that the researcher can obtain the results of interpretations objectively. The results of the interpretation obtained are negotiated, and agreed upon by the research subjects, which are used as data sources (Moleong, 2008), in order to build stronger research. So that research that is built stronger is able to uncover brightly, surely and recognized by others. Researchers need to understand the paradigm correctly. Understanding the paradigm in this research is very important, before going further in determining the methodology and research methods. Without understanding the paradigms, methodologies and research methods, researchers can get lost and wrong in formulating conclusions or building theories.

\section{DISCUSSION}

\subsection{1 Unity of Heart in the Accounting of Church Tritugas}

Accounting that we know so far, includes material values (numbers), fair without exceptions, and the form of financial statements in accordance with financial accounting standards, even though the contents of the financial statements are not in accordance with reality. That is, the numbers or the contents of financial statements may have been modified, the aim is to enrich themselves and their families. Therefore, in order for accounting to become more humanitarian, it is expected that the church tritugas accounting values applied to church organizations will be able to change the behavior of accountants in the right direction and provide moral legitimacy in accounting practices.

The church tritugas accounting practice is financial information, which is accounted for on the basis of God's Word, and is useful for bringing peace to others. "Mr. K said that the church tritugas accounting assignment, with the hope of providing a new perspective on koinonia, marturia, and diakonia as a valuable form of moral learning, would improve the perspective of accounting practitioners in nonprofit organizations". The phrase Mr. K has a moral meaning that has been built into a spiritual foundation in the practice of accounting church tritugas, then the moral strength and unity of the hearts of his people who become messages in the Bible can be realized.

The church is now faced with concrete problems and not only abstract. The church struggles with its goals, namely people and real problems. Thus, the church is required to work manifestly in a humanistic spirit. The church cannot work abstractly, like doing theology, or dealing solely with knowledge of God. "Mrs. E revealed the church's accounting responsibilities teach us to be the right doers, and be winners". The church is still prepared to be the winner, in every fellowship of the righteous (koinonia), witness of the righteous (marturia) and the service of the righteous (diakonia). That means there is a true commitment from management, and the congregation to really do fellowship, witness and service properly, to share in suffering for the sake of the gospel.

Church tritugas accounting is called to preach the good news of God, for all people to believe and be saved (Acts 2: 4147). Services must be open, dynamic and dialogic in the situation of development in society with an attitude of unity, honesty, positive, critical, creative and realistic. Accountability of the church's duties as a service of love, if the service appears as an equilateral triangle, consisting of true fellowship, testimony and service, the three cannot be separated. Koinonia can be described in chart 3.1 as follows:

Chart 3.1 Koinonia - Partnership

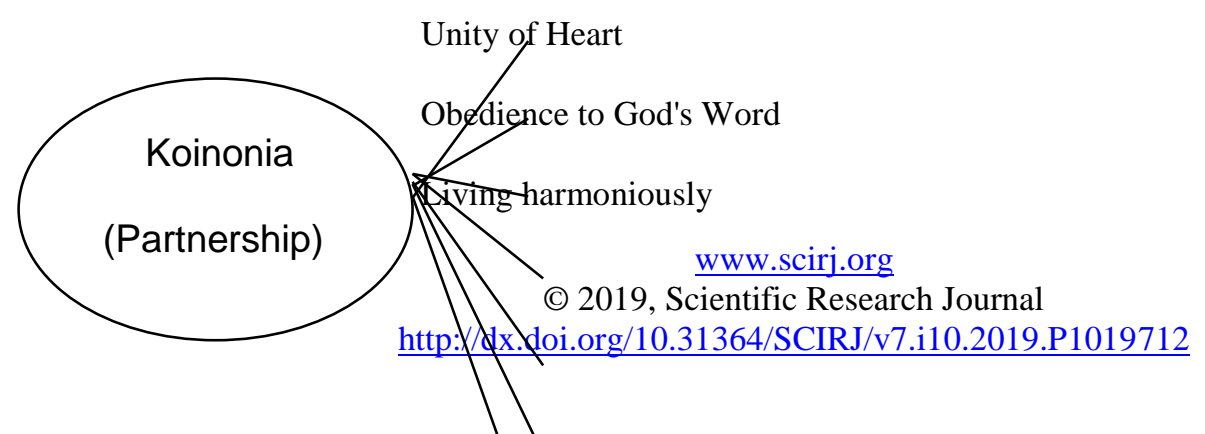




\section{Empathy, Love, please God \\ Bring blessings to others \\ Teaching and reprimanding \\ Pleases God}

Source: Researcher's processed data

So, fellowship has a basis and purpose that comes from Jesus Christ. These core and objectives cannot be replaced by other bases and objectives. If this fellowship replaces the foundation which has been laid by and in Jesus Christ, this fellowship will lose its essence, and is basically no longer a fellowship. Koinonia is a reflection of accounting practices, can be implemented in the collection of evidence of financial transactions carried out correctly on the basis of obedience to God's Word.

Marturia comes from Greek. Marturia means testimony. Witness any truth. Marturia in the Bible gives meaning, among others. Witness a fact or truth (Luke 24:48). Bear good witness about someone (Luke 4:22). Management that is alive today is not an eyewitness to the work of saving Jesus Christ, but management is a witness of belief, so that the life of management and His people must be colored with true belief. In the form of management sermons and the behavior of His people can testify, but more than that management life is a living sermon. Marturia gives a reflection that in the practice of accounting the church's responsibilities are a form of testimony to facts or truths, in terms of accountability for financial statements, based on obedience to God's word, to bring peace to all people. Marturia can be described in Chart 3.2 as follows:

\section{Chart 3.2. Marturia - Testimony}

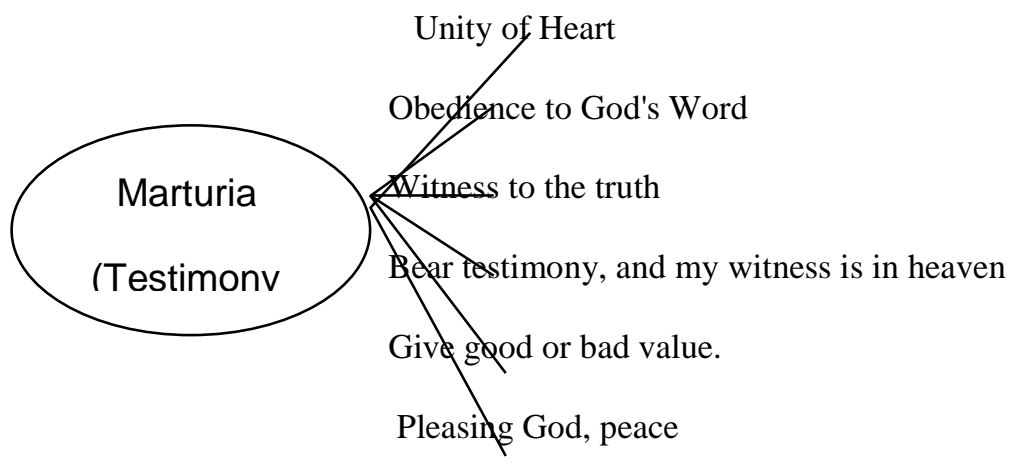

Source: Researcher's processed data

Diakonia comes from Greek. The deaconee verb is to serve. The deaconess noun is a true servant. The noun diasonos are servants. Jesus' view of service comes from the commandments in the Bible, about love for fellow human beings in everything. Diakonia means servitude. From this deeper perspective, Jesus concludes in regard to His own nature according to Mark (19: 4345) and Matthew (20: 26-28), that the Son of Man did not come to be served, but to serve and give His life as a ransom for many people. Diakonia can be described in chart 3.3 as follows:

\section{Chart 3.3 Diakonia - Service}

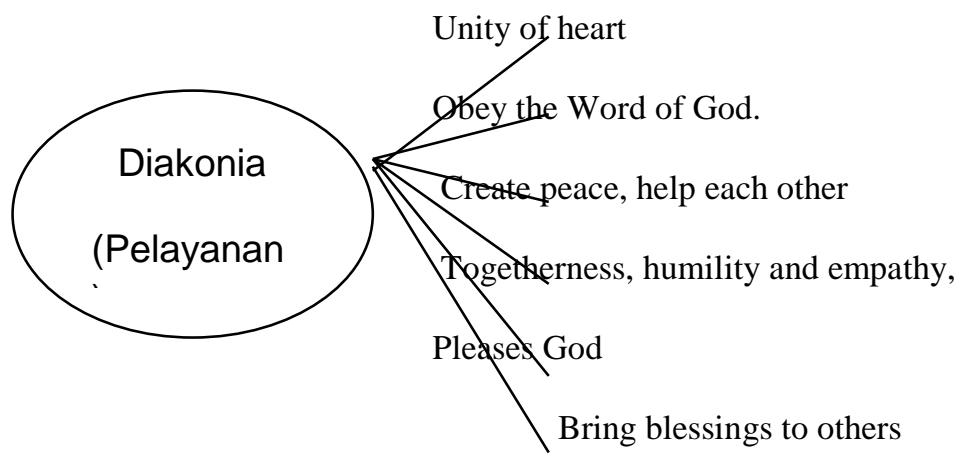

Source: Researcher's processed data

\subsection{Church Tritugas Accounting}

Church tritugas accounting is the duty of every human being to do what pleases God (2 Corinthians 5: 9-10, 1 Thessalonians 4: 1, Hebrews 13:21). Any activity carried out by humans on this earth is a belief given by God (Wiryoputro, 2002). "Mr. S said to do it with unity of heart, true and full of responsibility even though we are in need". Wiryoputro (2002) 
explained, there are three basic things that need to be understood in carrying out every activity of life, namely: first, obeying God's commands, as did Abraham (events 12: 1-4). Second, it becomes useful for others, as seen in the work of Jesus (John 5: 30,36). Third, it has obligations like those performed by Jesus, namely: bringing peace to others (John 3:15). As believers in accounting the call of the church reflects more on:

a). Reflection of obedience according to the truth of God's word, do the right recording, because God is the owner of life.

b). Reflections on the channel of blessing for others, and other creatures of God because of the position of humans as managers.

c). Reflection of peace for others because humans are required to make a report of accountability for all its activities to God as the ruler of heaven and earth.

Reflection of obedience in accordance with the truth of God's word, includes an assessment of the level of availability of implementing regulations, clarity of management arrangements in implementation, as well as obligations between practitioners of accounting practices in evaluating compliance with applicable regulations. Reflection of blessing channels for others and God's creations, including the interest in presenting financial statements. In the effort to present financial statements, moral legitimacy is required, from every practitioner in accounting practices of the church tritugas, to bring peace to others.

Refleksi damai sejahtera bagi orang lain, mencakup penilaian publik terhadap tata cara Reflections on peace for others, including public evaluation of the procedures, and the substance of accounting information. Then, analyzed in the dimensions of faith, knowledge, and action in the perspective of the church vocation tritugas. Thus, church tritugas accounting is a synergy, in achieving harmony in relationships by not abandoning moral values.

The values of morality contained in the church tritugas, have the main meaning, namely as an obligation manager, responsible for all his activities to God, as a trustee. In order to understand the implementation of accounting in the perspective of church vocation tritugas, researchers see accounting more as a process, which consists of three main functional activities, namely accounting records, actions (reporting), and responses, constituting the interaction between management, and the congregation in the process of carrying out accounting tritugas church. The interaction process is described in Chart 3.4 as follows

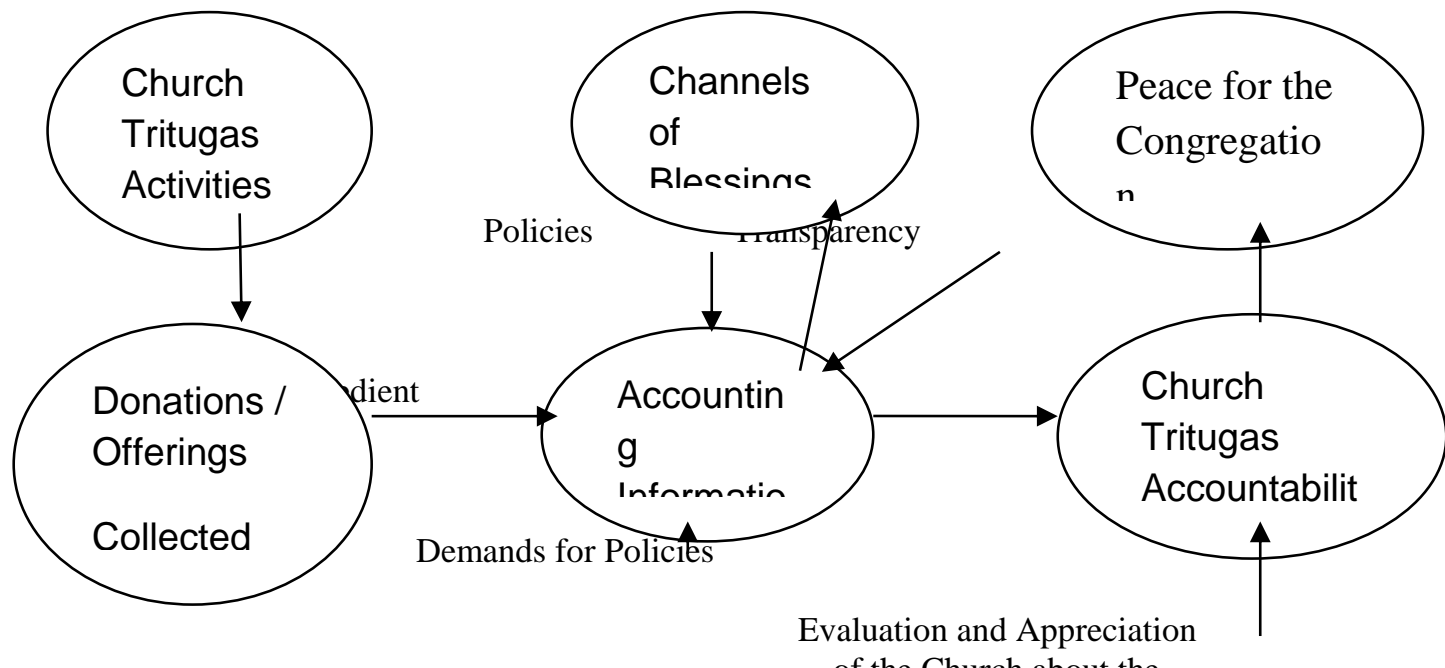

of the Church about the

Substance of Information

Chart 3.4 Interaction of Church Tritugas Accounting

Source: Researcher's processed data

Accounting information relating to management activities, to explain financial information about the design of the policy, relating to the resources obtained, and utilized in accordance with the rules. The rules in it consist of restrictions on the use of finance, allocation of resources, and the extent to which these resources have been reached. Actions relating to the activities of the congregation, to assess and submit demands to the manager, on the draft policy chosen. In this case, the claim to the manager is in the form of decrees based on the word of God, which are stated in the church tritugas (fellowship with love, serving with love, preaching the gospel with love). Responses, relating to the activities of managers to respond or follow up on a number of demands, which were submitted by the congregation on the basis of the church vocation tritugas.

On the dimension of responsibility, Jesus also emphasized loyalty, and honesty in handling things properly, and honestly including financial matters (Luke 6: 10-12). This is the responsibility and commitment of Christian teaching. The church as an institution which becomes the image of Jesus' presence in the world, is ready to implement transparent accounting principles. Transparent accounting, so that the church does not lose its right direction and orientation in managing church property. Life management will not be blessed, if his life is not right. In the Scriptures it is written, "You will know the truth, and the truth will set you free" (John 8:32). Therefore, management strives to continue to please God through the truth. Pleasing to God relates to God's saving work.

The form of God's saving work is expected for researchers to be able to build a fellowship of love, proclaim love and serve with love to the congregation and the community. These three things are the tritugas of the church vocation, which has an interdependent correlation between one another, the purpose of pleasing God. This can be said to be interdependent correlation 
because koinonia as a community will not be able to live, if there is no diakonia in the middle of the community. Likewise marturia, a ministry of proclaiming the kingdom of God. Through the gospel as the message of salvation will not live if there is no fellowship. The church cannot limit itself by only carrying out one task while forgetting the other. All these tasks are carried out simultaneously in order to achieve the perfection of the quality of love. The pattern of the manifestation of the quality of love is an increase based on love, self-control that does not seek self-gain. The manifestation of the quality of love is reflected in the implementation of church tritugas accounting, which is the focus of research for researchers. Description of the church tritugas in order to improve the quality of faith.

As a person who believes in God, who believes that God owns everything, so faithfulness in presenting church-related accounting information, a management must pay attention to Christian principles as he says in the Bible, that every step of man is controlled by God. God watches over bad people, and good people. God always watches from the beginning to the end of the year. Nothing in all creation is hidden from God's sight. Everything is uncovered and laid bare before the eyes of him to whom we must give account (Ibrani 4:13).

This Word of God gives a strong encouragement, so that in using the church accounting tritugas, every organization is always carried out with the fear of God. The Word of God is expected by the Christian faith, will affect the way of organizing, and behaving in real life, for church management. The practice of church tritugas accounting, basically there are several main components that need to be done, namely the party that is obliged to do church tritugas accounting, the party that has the authority to ask church tritugas accounting, the church tritugas accounting procedures and processes, the church tritugas accounting products themselves. An in-depth assessment of the church's level of accounting for the tritugas of the church can be done by presenting information on the basis of obeying God's commands. Useful for many people. And bring blessings and peace for others.

The next process, the principles of the church tritugas, which are built must pay attention to the recognition and measurement of each element of financial statements in the dimension of the Christian faith, by describing the dimensions of God's ownership, giving trust by God with the principle of honesty, and sincerity as built in the Christian faith. The Christian faith is implemented in the implementation of church tritugas accounting practices, there is no corruption. Mr. $\mathrm{K}$ revealed, must dare to say yes if yes, and no, if not, every Christian can live in holiness

No corruption has very deep meaning for internal and external institutions. For internal parties, it will facilitate attention in the relevant fields in taking corrective actions, or it can be used as an instrument to improve the quality, quantity and efficiency of services. Whereas for external parties, the application of this principle can be described as a guide, and at the same time as a source of information in accounting measurements. The phrase Mr. K has the meaning of unity in truth, because in the practice of accounting church tritugas, done with no modification. Unity can be done, if the procedures in preparing accounting reports can be done well. The preparation needs to be done by a management, who really has a strong commitment, not easily tempted by the tendency to use it for personal gain. Everything requires synchronization between conscience and risk, that is, a management who has an attitude of heart that fears God, and has a strong Christian faith, because what everything is done is for God.

Human Christian faith is God's management tool, which carries the mandate to manage God's resources on earth. Then it is possible for Christian values, to be injected into church tritugas accounting. Based on the expressions from the informants above, according to the researchers Christian values have been injected into the church tritugas accounting, which is proven through the statements of the informants. Then the researchers hypothesized that the word of God as a guide to behave, not to commit acts of corruption in the practice of church tritugas accounting. The Word of God guides every decision, and actions taken by management, to shape new realities. Because in turn this reality will capture other people, to enter into the network as a manifestation of management, who is aware of the nature of his life as a human being who has a conception, that life's mission is to be useful for fellow human beings.

The pattern of accounting that puts responsibility on God, will have implications that people can trust, for the development of Christian nuances. Where the reality that is created will be able to be translated in accounting procedures, processes and information. As well as operational mechanisms that can be implemented significantly in the practice of accounting for church tritugas. The church tritugas accounting model, which is Christian in nature, is very relevant to empirical reality, where management is brought closer to God.

This church accounting tritugas model shows that God is a strategic actor who must be the center of orientation towards the realization of accountability, therefore management empowers its position as the management of God on earth, as God is in His Word. On the basis of the fear of God, church tritugas accounting is used as the main indicator in the realization of the stewardship of accountability to God.

Therefore, in the concept of church tritugas accounting the element of stewardship is contained. Stewardship is the activity, relationships and responsibilities to make a single cycle. The activity in question is human efforts in managing and distributing assets as well as possible. While the relationship is more a form of coaching, as well as human socialization with others and the environment, to build cooperation, and good communication. While the responsibility of positioning an attitude of caring, both to fellow human beings, and the universe, as well as the attitude of godly life as a form of worship to God, which is the responsibility of church officials. In other words, stewardship related to the church tritugas of accounting, reflects how humans organize themselves, by showing a spiritually mature person, who prefers life with a philosophical foundation, namely 
living in a spirit that promotes a moral attitude, and refers to the principles of Christian faith, for the sake of pursue the goal of eternal life that God has promised, for everyone who does His will according to the principles of faith.

The principles of the Christian faith are implicitly, constituting the application and proof of devotion, through attitudes or actions, in the implementation of the church tritugas accounting practice. The Word of God says, "But be doers of the word, and not hearers only, deceiving yourselves (James 1:22)". But whoever examines the perfect law, which manages the law that liberates people, and he perseveres in it, so not only hear to forget it, but really do it, he will be happy by his actions.

Christians understand the word manager is called stewardship, or in the term church organization is called manager. This term describes God's relationship with humans, and vice versa humans with God. This means that the manager is a mechanism that is created, to manage all forms of resources, which are on earth that belong to the creator, given to humans, to manage accompanied by full trust in God, then humans are accountable to God.

Responsibility for stewardship is a manifestation of management's obedience to God, and is an important element in the Christian heritage. Supporting the statement above, Wiryoputro (2002) revealed that all human activities in this world must be ended with an accountability to God. God's Word 1 Peter 4: 5 "But they will have to give an account to him who is ready to judge the living and the dead".

Accountability to God is a must, as people who believe in God, then every individual in carrying out every activity must be in accordance with the provisions of God. God establishes the provisions that management must obey. Thus, management is responsible for everything they do to God, according to God's commands. The Word of God Deuteronomy (11:22) "For if you really must keep the commandments, which I tell you to do by loving the Lord your God, by living according to all the paths he shows".

This Word of God provides a teaching about how management lives its life. Therefore, management must live its life according to what is planned by the owner. Management must believe that in the creation of this earth, God has a separate plan for the survival of His people. The Word of God Jeremiah (29: 11) "For I know the designs which are in me concerning you, saith the Lord, which is the plan of peace and not an accident, to give you a hopeful future". This Word gives strength, a hopeful future. With hope, church management in every activity the church tritugas must always obey the commands of God. The church assigned tritugas activities must be of benefit to others, and those activities can bring peace to others.

Thus, this peace is expected to be able to generate full self-awareness, and one's obedience to God's power in the Christian life. In the Christian view, management is the person who has the task of managing, to God's property in this world, meaning that the position of management before God is as manager, and God as owner. Management must carry out what are the commands of God as the owner. Management can not be separated from responsibility, as managers of assets entrusted by God in this world.

The challenges faced by management in order to fulfill their obligations, to provide accountability for relevant financial information according to God's will. By placing responsibility for work in a real position, especially a sense of responsibility to God, the management orientation will be more focused on the organization, in stewardship of the work given, with full honesty and sincerity. Based on Christian values this causes conscious management, always grounded in the provisions of God in every mindset and action

\section{CONCLUSION}

The concept of church tritugas accounting, putting forward the responsibility to God, will have credible implications for the people, for the development of a Christian nuance. Where reality is created, it will be able to be translated in transactions, transaction evidence, journals, ledgers, trial balances, profit and loss reports, statement of changes in capital and balance sheets. As well as operational mechanisms that can be implemented in a real way, in the unity of the heart in the practice of accounting for church tritugas. The church accounting model, which is Christian in nature, is very relevant to empirical reality, where management is brought closer to God. This church tritugas accounting model, shows that God is a strategic actor who must be the center of orientation towards the realization of accountability, therefore management empowers its position as the management of God on earth, as God is in His Word. On the basis of the fear of God, church tritugas accounting is used as the main indicator in the realization of the stewardship of accountability to God. Research shows that the meaning of church tritugas accounting is that financial information that is generated is based on the unity of the hearts of the righteous, no modification (corruption), even though life is lacking. Hopefully this research can motivate church finance managers to continue to use church tritugas accounting as a guide in managing church finances.

\section{REFERENCES}

Bible. 2012. Publisher of the Indonesian Bible Society, Jakarta.

Basrowi, S. 2002. Qualitative Research Methods, Micro Perspectives, Surabaya : Insan Cendekian.

Booth, P. 1993. Accounting in Churches: A Research Framework and Agenda. 
Gallhofer, S. 2011. Emancipation the Spiritual and Accounting. Critical Perspectives on Accounting 22, 500-509.

IAI. 2009. Financial Accounting Standards Jakarta: Salemba Empat.

Moleong, L. 2008. Metodologi Penelitian Kualitatif. Penerbit PT. Remaja Rosda Karya, Bandung.

Nasution, S. 1922. Metode Research. Jakarta: Bumi Aksara.

PSAK No.45. 2012. Pelaporan Keuangan Entitas Nirlaba.

Quattrone, P. 2004. Accounting for God: Accounting and Accountability Practices In The Society of Jesus (Italy, XVI - XVII centuries), Accounting, Organizations and Society, 29, 647-683. Rahardi, F. 2007. Menguak Rahasia Bisnis gereja, Visi media, Cerdas Mandiri .Ciganjur Jayakarta.

Reed, C.G. \& Baker, C.T. 2003. Religious Prohibitions Against Usury. Explorations in Economic History, 40, 347-368.

Rosenau, P. M. 1992. Post-Modernism and the Social Sciences; Insights, Inroods, and Intrusions. Pinceton ,Nj; Princeton University Press.

Sabrino, J. 1984. The True Church and the Poor. Marykoll,N.Y: Orbis Books..

Sanders, P. 1982. Phenomenology. A New Way of Viewing Organizational Research, The Academy of Management Review, July: 353-360.

Sinclair, A. 1995. The Chamelon of Accountability: Forms and Discourses, Accounting, Organization and Society. $541-573$.

Stanbury W.T. (2003). Accountability to Citizens in the Westminister Model of Government: More Myth Than Reality. Vancouver: The Fraser Institute.

Triyuwono, I. 2004. Trust the Divine Symbol: Interpretation in Context os Islamic Banking and Accounting Practices. Presentation at the Fourth Asian Pacific nterdiciplinary Research in Accounting Conference Singapure 4 to 6 July.

Wiryoputro, S. 2002. . Fundamentals of Christian Management Jakarta: BPK Gunung Mulia. Yayasan 